\title{
ANALISIS PERATURAN PEMERINTAH NOMOR 101 TAHUN 2014 TERHADAP BAHAN BERBAHAYA DAN BERACUN DI KOTA BATAM
}

\author{
Ukas $^{1}$, Zuhdi Arman ${ }^{2}$ \\ 1,2Fakultas Ilmu Sosial dan Humaniora Universitas Putera Batam \\ Jalan R. Soeprapto Muka Kuning, Kibing, Kec. Batu Aji, Kota Batam, Kepulauan Riau 29434 \\ Korespondensi : ukasibrahim@gmail.com
}

\begin{abstract}
Environment is very important in the human life cycle. In modern times problems arise regarding the environment. In this paper the issue raised is the impact of environmental pollution caused by sewage and waste as well as the government's efforts to prevent environmental pollution.To these problems occurs line with technological developments who without pay attention to environment. Environmental pollution has an impact on health, aesthetics, economic losses, and disruption of natural ecosystems. The method used in this paper is a juridical-empirical, theoretical approach using facts and laws. The conclusion of these problems is the lack of awareness on the part of industry employers and the community to protect the environment from pollution and waste bins will berdampaknya the destruction of natural ecosystems and reduced environmental quality standards.
\end{abstract}

Keywords; Government Regulations, Hazardous, Toxic Material.

\begin{abstract}
Abstrak
Lingkungan merupakan hal yang sangat penting dalam siklus kehidupan manusia. Di zaman moderen ini timbul permasalah mengenai lingkungan. Dalam tulisan ini permasalahan yang diangkat adalah dampak pencemaran lingkungan yang disebabkan oleh limbah dan sampah serta upaya pemerintah dalam mencegah pencemaran lingkungan hidup. Permasalahan tersebut terjadi seiring dengan perkembangan teknologi yang tanpa memperhatikan lingkungan. Pencemaran lingkungan memiliki dampak terhadap kesehatan, estetika, kerugian ekonomi, dan terganggunya ekosistem alami. Metoda yang digunakan dalam karya tulis ini adalah yuridis-empiris, dengan menggunakan teori pendekatan fakta dan peraturan perundang-undangan. Kesimpulan dari permasalahan tersebut adalah dengan tidak adanya kesadaran dari pihak pengusaha industri dan masyarakat untuk melindungi lingkungan hidup dari pencemaran limbah dan sampah akan berdampaknya pada rusaknya ekosistem alami serta berkurangnya baku mutu lingkungan.
\end{abstract}

Kata kunci; Peraturan Pemerintah , Bahan Berbahaya, Beracun. 


\section{PENDAHULUAN}

Dalam perkembangan sejak kemerdekaan sampai dengan sekarang ini Indonesia merupakan Negara demokrasi yang menerapkan hukum. ${ }^{1}$ Dalam mewujudkan tujuan berbangsa dan bernegara, Negara memiliki peran dan tanggung jawab untuk mendorong peningkatan kesejahteraan masyarakat dengan tetap memperhatikan lingkungan termasuk manusia dan makhluk hidup lainnya. Pembangunan sebagai upaya untuk meningkatkan kualitas kehidupan sangat tergantung pada ketersediaan sumberdaya. Kebijakan optimalisasi kepentingan ekonomi dan lingkungan selalu menjadi isu dalam pembangunan termasuk Indonesia. Peran Negara melalui organ-organnya memegang peran penting untuk tetap mempertahankan keseimbangan tujuan ekonomi dan lingkungan untuk memberikan keadilan antar generasi. ${ }^{2}$

Dalam tatanan lingkungan hidup yang termuat dalam Undang-Undang Nomor 23 Tahun 1997 yang diubah dengan Undang-Undang Nomor 32 Tahun 2009 tentang Perlindungan dan Pengelolaan Lingkungan Hidup, khususnya masalah pencemaran yang bermuara pada limbah bahan berbahaya dan beracun (limbah-B3), hal ini disebabkan karena berbagai komponen berupa bentuk energi, zat kedalam lingkungan baik yang ada pada tatanan lingkungan di udara, darat bahkan di laut dan atau di air (termasuk danau sungai dan pantai), maka disepanjang perairan atau pantai bisa tercemar limbah bahan berbahaya dan beracun (limbah-B3). Bahaya hal seperti tersebut telah tercantum dalam UUPPLH Nomor 32 Tahun 2009.

Secara umum pencemaran bahan berbahaya dan beracun (limbah-B3) telah diatur dan tersebar dalam sejumlah Peraturan Perundang-undangan dalam berbagai tingkat dan dikenal sejak ordonnantie, antara lain Gevaarlijke Stopffen Ordonnantie stb 1949 No. 337, Peraturan Pemerintah No. 7 Sisa Bahaya Tahun 1993 tentang Pengawasan atas Peredaran, Penyimpanan dan Pengawasan Pestisida, SK Menteri Perindustrian No. 148/M/SK/1985 tentang Pengamanan Bahan Beracun dan Berbahaya (B3) dari perusahaan industri, Undang-Undang No 10 Tahun 1997

\footnotetext{
1 Zuhdi Arman, Tinjauan Terhadap Sistem Multi Partai Dalam Sistem Pemerintahan Presidensial Di Indonesia Pada Era Reformasi, Jurnal Cahaya Keadilan, 6 (1), 2018, h. 23.

2 Maret Priyanta, Regulasi Perizinan Mendirikan Bangunan dalam Mendukung Kemudahan Berusaha Menuju Bangsa Yang Adil dan Makmur, Jurnal Magister Hukum Udayana, 8(3), 2019, h. 372. 10.24843/JMHU.2019.v08.i03.p6
} 
tentang Sisa Bahaya Nuklir. ${ }^{3}$ Dari hal di atas tetap berada pada tatanan UndangUndang Nomor 23 Tahun 1997 yang diubah dengan Undang-Undang Nomor 32 Tahun 2009 tentang Perlindungan dan Pengelolaan Lingkungan Hidup, kemudian dijabarkan dan bentuk implementasi dalam beberapa Peraturan Pemerintah pusat dan Pemerintah Daerah terutama Peraturan Pemerintah No. 101 Tahun 2014, dan peraturan lainnya yang terkait dengan penataan dan pengawasan kelesterian lingkungan termasuk amdal, mutu air dan lain-lainnya.

Substansi hukum lingkungan mencakup sejumlah ketentuan-ketentuan hukum tentang upaya-upaya mencegah dan mengatasi masalah-masalah lingkungan hidup, tentang pembidangan dalam hukum lingkungan, tampaknya diantara para sarjana tidak terdapat kesamaan pandang. Van den Berg memahaminya sebagai hukum bencana(rampen reclit), hukum kesehatan lingkungan (milieulygiene recht), hukum tentang sumber daya alam (recht betreffende natuurlijk rijkdommen) atau Hukum Konservasi, Hukum tentang Pembahagian Pemakaian Ruang.

Berdasarkan peraturan-peraturan yang ada, menjelaskan dan memberikan pemahaman bahwa Limbah Bahan Berbahaya dan Beracun (Limbah-B3) yaitu bahan yang karena sifat dan konsentrasi, jumlahnya baik langsung maupun tidak langsung dapat mencemarkan dan merusak lingkungan hidup. Pemahaman Pasal 1 ayat (17) dalam Undang- Undang Lingkungan Hidup Tahun 1997 adalah adanya sisa-sisa usaha atau kegiatan industri dan lainnya yang mengandung bahan berbahaya dan atau racun yang karena sifatnya atau konsentrasinya jumlah baik langsung maupun tidak dapat mencemarkan atau merusak lingkungan hidup. ${ }^{4}$

Secara teoritik, limbah dapat dikategorikan sebagai limbah B3 jika setelah melalui uji karakteristik limbah itu memiliki karakter atau sifat-sifat antara lain mudah meledak, mudah terbakar, bersifat reaktif dan beracun dan lain-lain. Dalam pengaturan dan pengelolan pencemaran limbah berbahaya dan beracun (limbah B3) terdapat dalam sejumlah Peraturan Perundang-undangan dalam berbagai tingkatan, seperti yang diatur dalam Peraturan Pemerintah No. 7 Tahun 1993 tentang Pengawasan Atas Peredaran Limbah B3, penyimpanan dan pengunaan pestisida,

\footnotetext{
${ }^{3}$ Munadjat, D, Hukum Lingkungan, Bandung: Binacipta, 2011, h. 9

${ }^{4}$ Rahmadi, T. Hukum Lingkungan di Indonesia, Jakarta: PT Rajagrafindo Persada, 2014, h. 16
} 
undang-undang Tahun 1997 menyebutkan bahan yang kerena zatnya mencemarkan racun limbah B3 adalah kegiatan penyimpanan limbah B3. Bahan Berbahaya dan Beracun (B3) adalah zat, energi, atau komponen lain yang karena sifat, konsentrasi dan jumlahnya, baik secara langsung maupun tidak langsung, dapat mencemarkan, merusak lingkungan hidup, dan dapat membahayakan lingkungan hidup, kesehatan, kelangsungan hidup manusia serta makhluk hidup lainnya. ${ }^{5}$

Kasus limbah minyak hitam mencemari pesisir di Pulau Labu, Kelurahan Batu Legong, Kecamatan Bulang, Batam, juga belum ada menemukan kejelasan. Pencemaran yang terjadi tepat di depan pantai Dapur 12 Sagulung, Batam ini sebelumnya telah mendapat perhatian Komisi III DPRD Batam. Beberapa hari dilaporkannya pencemaran limbah minyak, Komisi III DPRD Kota Batam langsung melakukan sidak ke lokasi. Selain itu, juga digelar Rapat Dengar Pendapat (RDP) dengan melibatkan instansi terkait dan pihak perusahaan. ${ }^{6}$

Selain itu pencemaran juga disebabkan oleh praktek tank cleaning alias pembersihan tangki. Membersihkan tangki dilakukan sebelum kapal masuk ke Singapura, masalahnya jasa ini ada yang legal dan ilegal. Yang legal penyedia jasanya akan mengolah kembali sisa minyak pembersihan. "Ada juga tank cleaning jadi kapalkapal yang mau masuk Singapura dia membersihkan dulu sisa-sisa pembersihan oli bekas, supaya nggak kena denda di Singapuranya. Nah di daerah Batam-Bintan itu ada jasa yang bersihkan tangki minyak, cuma ada yang legal dan illegal. ${ }^{7}$

Sehubungan dengan masalah-masalah di atas, maka Pemerintah RI pada tanggal 17 Oktober 2014 mengeluarkan Peraturan Pemerintah No. 101 Tahun 2014 tentang Pengelolaan Limbah Bahan Berbahaya dan Beracun (limbah B3). Peraturan Pemerintah ini merubah Peraturan Pemerintah No. 85 Tahun 1999 yang sudah tidak berlaku lagi. Peraturan Pemerintah No. 101 Tahun 2014 ini merupakan amanat Undang-Undang No. 32 Tahun 2009 tentang Pengelolaan dan Perlindungan Lingkungan Hidup (UUPPLH) tepatnya pada Pasal 59 tentang Strategi Nasional untuk pembangunan berkelanjutan. Peraturan Pemerintah membahas bagaimana

${ }^{5}$ Utami, L., \& Musyarofah, S. (2021). Pengelolaan Limbah Bahan Berbahaya dan Beracun di RS “X”. Jurnal Ilmiah Permas: Jurnal Ilmiah STIKES Kendal, 11(1), 171-178.

6 https://kumparan.com/kepripedia/warga-pertanyakan-kejelasan-kasus-limbah-minyak-di-pesisir-pulau-labubatam-1vL93BO4vNg/full, diakses pada tanggal 22 April 2021

7 https://finance.detik.com/berita-ekonomi-bisnis/d-4727901/ulah-kapal-nakal-laut-kepulauan-riau-tercemarlimbah-minyak. diakses pada tanggal 22 April 2021 
pengelolaan limbah B3 harus dilakukan secara terpadu karena dapat menimbulkan kerugian terhadap kegiatan manusia dan mahluk hidup lainnya, dan bahkan mengacam kelestarian lingkungan itu sendiri.

Pencemaran lingkungan hidup yang bermuara pada terganggunya ekosistem lingkungan, dan masuknya zat-zat ke dalam lingkungan yang menyebabkan lingkungan itu tidak berfungsi dengn baik. Khusus pencemaran lingkungan yang berakibat munculnya bahan berbahaya dan beracun khususnya lingkungan dikota batam (lebih spesifik lagi wilayah sungai, laut, dan pantai), disebabkan limbah yang ada dipinggir laut seperti dipantai Nongsa dan tempat-tempat lainnya bisa saja dari buangan zat-zat dan atau bocoran Kapal (Asing dan lain-lain) karena sengaja atau tidak sengaja kapal itu bocor akhirnya akibat dirasakan pantai terdekat. Begitu juga tempat usaha lain yang kurang memahami atau pengelolaannya belum begitu benar sehingga terjadi pencemaran dengan mengakibatkan B3.

Dari apa yang dijelaskan di atas dapat dipahami bahwa perlindungan hukum lingkungan dari pencemaran lingkungan mencakup pengendalian pencemaran lingkungan, penyelesaian sengketa lingkungan, dan hukum konservasi sumber daya alam. Hukum Perencanaan lingkungan hidup mencakup bahasan analisis mengenai dampak lingkungan hidup dan pertumbuhan dan pemanfaatan ruang telah berkembang sesuai perkembangan manusia dan lingkungan dalam wilayah tersebut. Hukum pencemaran lingkungan, antara lain meliputi ketentuan-ketentuan hukum tentang pencegahan dan penanggulangan pencemaran lingkungan, dalam bidang ini berkaitan dengan izin pembangunan limbah, baku mutu lingkungan dan analisis mengenai dampak lingkungan. Berdasarkan uraian diatas, maka rumusan masalah yang diteliti adalah Bagaimana pengelolaan limbah bahan berbahaya dan beracun di wilayah laut khususnya dan lingkungan laut di Kota Batam? Dan Bagaimana upaya penanganan dan sanksi yang dilakukan oleh pemerintah dalam mengurangi limbah B3 tersebut di wilayah Kota Batam?

\section{METODE PENELITIAN}

Jenis penelitian ini adalah penelitian deskriptif kualitatif. Penelitian deskriptif kualitatif adalah salah satu metode untuk mendapatkan kebenaran dan tergolong sebagai penelitian ilmiah yang dibangun atas dasar teori-teori yang berkembang dari 
penelitian dan terkontrol atas dasar empirik. Data dalam masalah penelitian bisa berasal dari dokumentasi hasil penelitian, pengawasan, evaluasi, pengamatan pendahuluan, dan pernyataan orang-orang yang patut dipercaya. ${ }^{8}$

Dalam penelitian ini, peneliti berusaha menganalisis Implementasi, Implikasi dan peran Pemerintah dalam upaya pelaksanaan dan pengelolaan limbah bahan berbahaya dan beracun di wilayah laut khususnya dan lingkungan laut di Kota Batam maka relevan jika penelitian ini dilakukan dengan menggunakan pendekatan kualitatif. Lokasi yang dilakukan dalam penelitian bertempat di Kantor Dinas Lingkungan Hidup Kota Batam dan kantor-kantor lembaga terkait dengan kebutuhan penelitian.

\section{PEMBAHASAN}

\subsection{Pengelolaan Limbah Bahan Berbahaya dan Beracun di wilayah laut Kota Batam}

Substansi hukum lingkungan mencakup sejumlah ketentuan-ketentuan hukum tentang upaya dalam mencegah dan mengatasi masalah lingkungan hidup. Tentang pembidangan dalam hukum lingkungan, tampaknya diantara para sarjana tidak terdapat kesamaan pandang. Perlindungan hukum lingkungan dari pencemaran lingkungan mencakup penyelesaian pencemaran lingkungan, penyelesaian sengketa lingkungan, dan hukum konservasi sumber daya alam. Hukum Perencanaan lingkungan hidup mencakup bahasan analisis mengenai dampak lingkungan hidup dan pertumbuhan dan pemanfaatan ruang telah berkembang sesuai perkembangan manusia dan lingkugan dalam wilayah tersebut. Hukum pencemaran lingkungan, antara lain meliputi ketentuan-ketentuan hukum tentang pencegahan dan penanggulangan pencemaran lingkungan, dalam bidang ini berkaitan dengan izin pembangunan limbah, baku mutu lingkungan dan analisis mengenai dampak lingkungan.

Berdasarkan teori Toxic, bahan padat atau cair yang mengandung elemen yang membahayakan adalah buangan material yang terdapat dalam kondisi biasa pada

8 Soerjono, S, Pengantar Penelitian Hukum, Jakarta: UI-Pres, 2011, h. 12 
lingkungan yang membahayakan yang harus ditiadakan dan lingkungan harus diselamatkan. ${ }^{9}$

Limbah bahan berbahaya dan beracun (B3) di Kota Batam meliputi : ${ }^{10}$

1. Limbah tumpahan minyak hitam dan sejenisnya

Limbah tumpahan minyak hitam ini pada umumnya mengandung pencemaran lingkungan yang lebih serius lagi adalah mengandung bahan berbahaya dan beracun bagi masyarakat sekitar wilayah/pantai/sungai yang selama ini ditempati atau pemukiman masyarakat pantai. Hal ini berulang kali terjadi apalagi limbah seperti ini dianggap masyarakat sebagai limbah musiman karena hanya ada pada saat angin utara setiap tahunnya. Limbah ini diprediksi dari tumpahan atau kapal yang sedang berlayar yang bocor sebagai akibatnya minyak tumpahan tersebut sampai kepantai dan terjadilah pencemaran laut. Jika limbah B3 ini dimakan oleh ikan dan atau sejenisnya kemudian ikan tersebut dimakan lagi oleh manusia, akibatnya akan terganggunya kesehatan dan yang lebih fatal lagi bisa berakibat kanker.

2. Limbah hasil sisa usaha industri, dan sejenisnya.

Limbah hasil usaha industri yang tidak disadarti bocor atau tidak tertata dengan baik, akibatnya limbah tersebut muncul ditengah-tengah masyarakat baik dipemukiman maupun di wilayah yang dekat dengan industri, hal ini juga berakibat fatal karena kemungkinan besar mengandung bahan beracun dan berbahaya (B3).

3. Pengelolaan pembuangan sampah yang tidak sesuai aturan yang ada, dan sejenisnya.

Pengelolaan pembuangan sampah, baik sampah masyarakat maupun sampah perusahaan yang terlambat diangkut apa karena keterbatasan tenaga dan angkutan/fasilitas yang berkibat sampah-sampah tersebut berserakan dan atau sebahagiannya dibakar begitu saja oleh masyarakat dengan alasan mengurangi khususnya pada wilayah-wilayah tertentu. Akibatnya dapat bahkan menimbulkan pencemaran lingkungan tempat

${ }_{9}^{9}$ Selamet, J, 2012, Kesehatan Lingkungan, Yogyakarta, Gajah Mada UIPRESS. Hal. 94

${ }^{10}$ Hasil wawancara dan keterangan yang diperoleh dari Kantor Dinas Lingkungan hidup Kota Batam, pada tanggal 26 Agustus 2019. 
tinggal masing-masing dan lebih fatal lagi penyakit akan mudah terjangkit ke masyarakat dan lingkungan ini tidak asri seperti awalnya.

4. Kegiatan lainnya yang tidak sesuai dengan peruntukannya.

Kegiatan lainnya dari masyarakat yang kurang memahami lingkungan yang bersih dan manfaatnya masyarakat acuh dengan keberadaan lingkungan yang sehat itu, masalah pencemaran dan limbah B3 membuat masyarakat menganggap bukan masalah serius, yang penting masyarakat mengambil manfaatnya sesuai kehendaknya, tanpa memikirkan akibat yang lebih fatal baik untuk kepentingan lingkungan itu maupun kepentingan masyarakat secara luas.

Pemerintah memiliki peran dalam mempromosikan tata pemerintahan yang baik. ${ }^{11}$ Pengelolaan limbah bahan berbahaya dan beracun (B3) merupakan salah satu rangkaian kegiatan yang mencakup penyimpanan, pengumpulan, pemanfaatan termasuk penimbunan hasil pengelolaan, sehingga dapat dipahami bahwa pelaku pengelolaan limbah bahan berbahaya dan beracun (B3) antara lain :

1. Pengangkut limbah bahan berbahaya dan beracun (B3)

2. Pengumpul limbah bahan berbahaya dan beracun (B3)

3. Pengangkut limbah bahan berbahaya dan beracun (B3)

4. Penuntutan bahan berbahaya dan beracun (B3) (Sugiono, 2012).

Dalam penelitian terdahulu yang berjudul Implementasi Pengelolaan Limbah Bahan Berbahaya dan Beracun (B3) di PT. Clariant Adsorbent Indonesia, Memaparkan tiap kegiatan produksi di tempat kerja selalu menghasilkan limbah, salah satunya limbah B3. Perusahaan telah menerapkan pengelolaan limbah B3. Hal ini telah sesuai dengan Peraturan Pemerintah No. 101 Tahun 2014 Tentang Pengelolaan limbah Bahan Berbahaya dan Beracun akan tetapi masih ada beberapa aspek terkait kualitas bangunan penyimpanan limbah B3 yang belum sesuai dengan Keputusan Kepala Bapedal No.1 Tahun 1995 Tentang Tata Cara Persyaratan Teknis Penyimpanan dan Pengumpulan Limbah Bahan Berbahaya dan Beracun. ${ }^{12}$

Sesuai Peraturan Pemerintah No. 101 Tahun 2014, Peraturan lainnya yang terkait dan analisa sementara bahwa mayoritas industri dan kerajinan masyarakat

11 Citra, Sukmadilaga, Good Governance Implementation In Public Sector: Exploratory Analysis of Government Financial Statements Disclosures Across ASEAN Countries, Procedia Social and Behavioral Sciences, 2015, h. 24

12 Norma Diantika, UNS-Fak. Kedokteran Prog. DIII Hiperkes dan Keselamatan Kerja-R0016073-2019 
lainnya belum (tidak) menyadari bahwa limbah tersebut dalam kategori limbah bahan berbahaya dan beracun (B3). Sehingga pihak industri dan atau kegiatan lainnya oleh masyarakat akhirnya di buang begitu saja kesistem perairan dan atau tempat lainnya di wilayah darat tanpa adanya proses pengelolaan. Pada prinsipnya pengelolaan penanganan limbah bahan berbahaya dan beracun (B3) harus ditimbun, dibakar atau dibuang kelingkungan, karena mengandung bahan berbahaya dan beracun (B3) yang dapat membahayakan manusia dan mahluk lainnya. Beberapa metode penanganan bahan beracun (B3) antara lain : ${ }^{13}$

1. Metode pengelolahan secara kimia, fisika, dan biologi

2. Metode pembuangan limbah bahan berbahaya dan beracun

3. Sumur dalam/sumur injeksi (deep well inkjection).

Kemungkinan terjadinya kebocoran atau korosi pipa atau pecah lapisan batuan akibat gempa dan lain-lain sehingga limbah merembes kelapisan tanah, dan semua secara umum terjadi di kota Batam terhadap pengelolaan limbah bahan berbahaya dan beracun (B3) dan ini dilakukan pengawasannya oleh pemerintah dalam hal ini instansi yang terkait dengan lingkungan hidup, pemerintah dan masyarakat untuk upaya mengurangi tersebarnya bahan berbahaya dan beracun (B3) di wilayah kota Batam dan sekitarnya.

\subsection{Upaya Penanganan dan Sanksi yang dilakukan oleh Pemerintah untuk Masyarakat dalam Mengurangi Limbah B3 di Wilayah Kota Batam}

Konvensi tentang Hukum Laut Internasional disahkan pada tahun 1982 dalam sidang umum Perserikatan Bangsa-Bangsa. Konvensi ini mulai berlaku tahun 1996 setelah diratifikasi 60 negara. Dalam konvensi ini Negara-negara harus mengambil tindakan untuk mencegah, mengurangi dan mengendalikan pencemaran lingkungan laut menggunakan cara yang paling praktis sesuai kemampuannya masing-masing dan menjamin agar kegiatan-kegiatan dibawah yuridiksi atau pengawasannya tidak mengakibatkan pencemaran dan menjamin pencemaran tersebut tidak menyebar ${ }^{13}$ Agustiningsih, Setia dan Sudarno. 2012. Analisis Kualitas Air Dan Strategi Pengendalian Pencemaran Air Sungai
Blukar Kabupaten Kendal. Jurnal Presipitasi, 9(2) 
melampaui daerah-daerah yang ada dibawah pelaksanaan hak-hak kedaulatannya. Tindakantindakan yang diambil direncanakan untuk mengurangi sejauh mungkin: ${ }^{14}$

1. Dilepaskannya bahan-bahan yang beracun, berbahaya atau mengganggu, khususnya bahan-bahan yang persisten, yang berasal dari sumber daratan atau melalui udara atau karena dumping.

2. Pencemaran dari kendaraan air, terutama tindakan-tindakan untuk mencegah kecelakaan dan yang berkenaan dengan keadaan darurat, untuk menjamin keselamatan operasi di laut, untuk mencegah terjadinya pembuangan yang disengaja atau tidak serta mengatur desain, konstruksi, peralatan, operasi dan tata awak kendaraan air

3. Pencemaran dari instalasi-instalasi dan alat peralatan yang digunakan dalam eksplorasi atau eksploitasi kekayaan alam dasar laut dan tanah dibawahnya khususnya tindakantindakan untuk mencegah kecelakaan dan yang bertalian dengan keadaan darurat untuk menjamin keselamatan operasi di laut serta mengatur desain, konstruksi, peralatan, operasi dan tata awak instalasi-instalasi atau peralatan termaksud

4. Pencemaran dari lain-lain instalasi dan peralatan yang dioperasikan dalam lingkungan laut, terutama tindakantindakan untuk mencegah kecelakaan dan yang berkenaan dengan keadaan darurat, untuk menjamin keselamatan operasi di laut, mengatur desain, konstruksi, peralatan, operasi dan tata awak instalasi-instalasi atau peralatan termaksud.

Dalam Undang-Undang Nomor 32 Tahun 2009 tentang Perlindungan dan Pengelolaan Lingkungan Hidup (UUPPLH) Berkaitan Pengendalian Pencemaran Bahan Berbahaya dan Beracun di Wilayah Laut yang Berada dibawah Kedaulatan Indonesia. ${ }^{15}$ Aspek hukum administrasi pengendalian pencemaran B3 di Wilayah Laut yang Berada dibawah Kedaulatan Indonesia dalam UUPPLH mencakup ketentuan mengenai Pengelolaan B3 dan Limbah B3, Penanggulangan dan Pemulihan Pencemaran B3, Larangan Memasukkan B3 dan limbah B3, Pengawasan B3, sanksi administratif bagi pemcemar B3 dan hak gugat pemerintah dan gugatan administratif berkaitan pencemaran B3. Aspek hukum pengendalian pencemaran B3 di Wilayah

14 Pasal 194 Konvensi PBB tentang Hukum laut Internasional.

15 Herlambang, A. 2006. Pencemaran Air dan Strategi Penanggulangannya. JAI, 2(1) 
Laut yang Berada dibawah Kedaulatan Indonesia mencakup penyelesaian sengketa diluar pengadilan, Ganti Kerugian Melalui Putusan Pengadilan, Tanggungjawab Mutlak dalam Pencemaran B3, Hak Gugat Masyarakat dan Organisasi Lingkungan Hidup.

Perlindungan dan pelestarian lingkungan perairan Indonesia, termasuk perlindungan dan pelestarian lingkungan perairan dari pencemaran B3 dilakukan berdasarkan peraturan perundang-undangan Nasional yang berlaku dan hukum 64 Internasional. ${ }^{16}$ Penegakan kedaulatan dan hukum di perairan Indonesia, ruang udara di atasnya, dasar laut dan tanah di bawahnya termasuk kekayaan alam yang terkandung di dalamnya serta sanksi atas pelang-garannya, dilaksanakan sesuai dengan ketentuan Konvensi hukum internasional lainnya, dan peraturan perundangundangan yang berlaku. ${ }^{17}$ Instrumen-instrumen hukum internasional berkaitan pengendalian pencemaran bahan berbahaya dan beracun di laut yang telah diratifikasi Indonesia sebagaimana diuraikan di atas antara lain: Konvensi Internasional Tentang Pencegahan Pencemaran dari Kapal Tahun 1973, Konvensi Internasional tentang Keselamatan Kehidupan Laut 1974, Konvensi Perserikatan Bangsa-Bangsa tentang Hukum Laut Internasional 1982. Peraturan perundangundangan Indonesia berkaitan pengendalian pencemaran bahan berbahaya dan beracun di laut Indonesia sebagaimana diuraikan di atas antara lain Undang-Undang Nomor 32 Tahun 2009 tentang Perlindungan dan Pengelolaan Lingkungan hidup dan Undang-Undang Nomor 17 Tahun 2008 tentang Pelayaran. Dengan demikian, perlindungan dan pelestarian lingkungan perairan dari pencemaran B3, baik dari aspek hukum administrasi, hukum perdata maupun hukum pidana dilakukan berdasarkan konvensi-konvensi dan undang-undang tersebut di atas.

Pengelolaan limbah B3 baik dari hasil sisa kegiatan usaha manusia baik yang berbadan hukum maupun yang tidak berbadan hukum. Limbah B3 ada yang digolongkan sebagai limbah yang sifatnya kosentrasinya langsung maupun tidak langsung merusak dan atau mencemarkan lingkungan hidup, selain rusaknya lingkungan maupun memberikan efek negatif (kesehatan) terhadap kesehatan masyarakat (manusia) dan makhluk hidup lainnya.

\footnotetext{
16 Pasal 23 Undang-Undang Nomor 6 Tahun 1996 tentang Perairan Indonesia
}

17 Pasal 24 Undang-Undang Nomor 6 Tahun 1996 tentang Perairan Indonesia 
Limbah bahan berbahaya dan beracun ini bersifat reaktif, korosif, mudah terbakar, dan lain-lain. Karena kenyataannya ada perusahaan yang belum dan sengaja acuh terhadap bahaya B3, maka memberikan efek jera kepada perusahaan dengan kegiatan usaha masyarakat, maka pemerintah mengeluarkan PP No. 101 tahun 2014 dimana PP tersebut tidak lain memberikan pedoman dengan pengelolaan B3 beserta sanksi secara umum yang ada didalam Undang-undang Nomor 32 tahun 2009 Tentang UUPPLH. Kedua peraturan perundangan tentang pencemaran dengan pengaturan limbah/pencemaran diudara dengan dilaut. Yang intinya perlu pembersihan lingkungan hidup agar lingkungan ASRI berkesinambungan dan hasilnya dapat dinikmati generasi berikutnya (wawasan lingkungan hidup). 18

Pencemaran lingkungan hidup yang bermuara pada terganggunya ekosistem lingkungan, dan atau masuknya zat-zat kedalam lingkungan yang menyebabkan lingkungan itu tidak berfungsi dengn baik. Khusus pencemaran lingkungan yang berakibat munculnya bahan berbahaya dan beracun khususnya dilingkungan Kota Batam (lebih spesifik lagi wilayah sungai -laut, dan pantai ) disebabkan limbah yang ada dipinggir laut seperti dipantai Nongsa dan tempat-tempat lainnya bisa saja dari buangan zat-zat dan atau bocoran Kapal karena sengaja atau tidak sengaja kapal itu bocor akhirnya akibat dirasakan pantai terdekat. Begitu juga tempat usaha lain yang kurang memahami atau pengelolaannya belum begitu benar sehingga terjadi pencemaran dengan mengakibatkan B3.19

Dengan ditemukannya bahan beracun dan berbahaya di wilyah kota Batam dan sekitarnya, hambatan yang dirasakan pemerintah antara lain :

a. Karena Kota Batam yang dikenal kota seribu ruko dan industri, dimana masyarakat belum menyadari sepenuhnya bahaya yang ditimbulkan oleh limbah industri atau usaha kegiatan lain masyarakat (usaha) untuk membuang limbah kesistem yang diatur oleh Peraturan Pemerintah.

b. Karena wilayah lautnya terbentang luas, dimana pengontrolannya dari pemerintah kurang maksimal.

\footnotetext{
${ }^{18}$ Ariyanti, S. 2010. Hubungan Jarak Sumur dari Sungai Tercemar Limbah Tapioka dengan Kadar Sianida. Jurnal Kemas, 5(2):106-111

${ }^{19}$ Kadek DH dan Konsukartha. 2007. Pencemaran Air Tanah Akibat Pembuangan Limbah Domestik Di Lingkungan Kumuh Studi Kasus Banjar Ubung Sari, Kelurahan Ubung.Jurnal Permukiman Natah, 5(2)
} 
c. Jumlah kegiatan rumah tangga yang menyebabkan sampahnya tidak langsung diangkut ketempat buang tetap, akibatnya bahaya racunnya, tenaga pengelolah baik sistem maupun anggarannya sangat terbatas kepada manusia dan atau makhluk lainnya.

d. Fasilitas dan prasarana lainnya termsuk pengangkutan yang serba terbatas.

Salah satu hambatan bagi pemerintah yang terkait, maka solusinya diperlukan sosialisasi dan bahaya dan mengandung racun, maka disarankan masyarakat, industri dan pelaku usaha lainnya yang terkait dengan limbah B3 benar-benar melaksanakan hasil usahanya dengan baik dengan pengawasan baik pengawasan dari pelaku industri usaha maupun dan masyarakat sebagai dukungan dalam melestarikan lingkungan hidup yang jauh dari bahan berbahaya dan beracun (B3).

Usaha pemerintah dalam penerapan PP No 101 tahun 2014 tentang pengelolaan B3 antara lain:

a. Memberikan pemahaman perintah undang-undang lingkungan hidup dan pengaturan PP tersebut secara umum kepada masyarakat dan atau badan usaha tentang pengelolaan, bahaya dan sanksinya.

b. Mengajak komponen masyarakat memperhatikan bahaya limbah yang ada dilingkungan masing-masing terutama dilingkungan usaha.

c. Memberi sanksi pada perorangan atau pelaku usaha terhadap hal-hal tentang pencemaran dan B3 khususnya di Kota Batam.

\section{PENUTUP}

\subsection{Kesimpulan}

Pencemaran lingkungan hidup yang bermuara pada terganggunya ekosistem lingkungan, dan masuknya zat-zat kedalam lingkungan yang menyebabkan lingkungan tidak berfungsi dengn baik. Khusus pencemaran lingkungan yang berakibat munculnya bahan berbahaya dan beracun dilingkungan Kota Batam. Hal ini disebabkan limbah yang ada dipinggir laut seperti dipantai Nongsa dan tempattempat lainnya. Pencemaran ini berasal dari buangan zat-zat dan bocoran Kapal karena sengaja atau tidak sengaja kapal itu bocor akhirnya akibat dirasakan pantai terdekat. Begitu juga tempat usaha lain yang kurang memahami atau pengelolaannya 
belum begitu benar sehingga terjadi pencemaran dengan mengakibatkan B3. Kota Batam yang dikenal kota seribu ruko dan industri, dimana masyarakat belum menyadari sepenuhnya bahaya yang ditimbulkan oleh limbah kesistem yang diatur oleh Peraturan Pemerintah, Karena wilayah lautnya terbentang luas, dimana pengontrolannya dari pemerintah kurang maksimal.

\subsection{Saran}

Diharapkan kepada pemerintah untuk meningkatkan pengawasan terhadap pencegahan akibat pencemaran B3.

\section{DAFTAR PUSTAKA}

\section{Buku}

Munadjat, D, Hukum Lingkungan, Bandung: Binacipta, 2011.

Rahmadi, T, Hukum Lingkungan di Indonesia, Jakarta: PT Rajagrafindo Persada, 2014.

Selamet, J, Kesehatan Lingkungan, Yogyakarta, Gajah Mada UIPRESS, 2012.

Soerjono, S, Pengantar Penelitian Hukum, Jakarta: UI-Pres, 2011.

\section{Jurnal}

Agustiningsih, Setia dan Sudarno. 2012. Analisis Kualitas Air Dan Strategi Pengendalian Pencemaran Air Sungai Blukar Kabupaten Kendal. Jurnal Presipitasi, 9(2).

Ariyanti, S. 2010. Hubungan Jarak Sumur dari Sungai Tercemar Limbah Tapioka dengan Kadar Sianida. Jurnal Kemas, 5(2):106-111.

Citra, Sukmadilaga, Good Governance Implementation In Public Sector: Exploratory Analysis of Government Financial Statements Disclosures Across ASEAN Countries, Procedia Social and Behavioral Sciences, 2015, h. 24.

Herlambang, A. 2006. Pencemaran Air dan Strategi Penanggulangannya. JAI, 2(1).

Kadek DH dan Konsukartha. 2007. Pencemaran Air Tanah Akibat Pembuangan Limbah Domestik Di Lingkungan Kumuh Studi Kasus Banjar Ubung Sari, Kelurahan Ubung.Jurnal Permukiman Natah, 5(2).

Maret Priyanta, Regulasi Perizinan Mendirikan Bangunan dalam Mendukung Kemudahan Berusaha Menuju Bangsa Yang Adil dan Makmur, Jurnal Magister Hukum Udayana, 8(3), 2019 h. 372. 10.24843/JMHU.2019.v08.i03.p6.

Norma Diantika, UNS-Fak. Kedokteran Prog. DIII Hiperkes dan Keselamatan KerjaR0016073-2019. 
Utami, L., \& Musyarofah, S. (2021). Pengelolaan Limbah Bahan Berbahaya dan Beracun di RS "X". Jurnal Ilmiah Permas: Jurnal Ilmiah STIKES Kendal,11(1), 171-178.

Ukas, Hukum Dan Pengelolaan Limbah Bahan Berbahaya Dan Beracun (B3) Wilayah Perbatasan Negara Di Kepulauan Riau, Vol 14 No 2 (2019): Jurnal Hukum Samudra Keadilan.

Zuhdi Arman, Tinjauan Terhadap Sistem Multi Partai Dalam Sistem Pemerintahan Presidensial Di Indonesia Pada Era Reformasi, Jurnal Cahaya Keadilan, 6 (1), 2018 h. 23. https://doi.org/10.33884/jck.v6i1.875.

\section{Website}

https://kumparan.com/kepripedia/warga-pertanyakan-kejelasan-kasus-limbahminyak-di-pesisir-pulau-labu-batam-1vL93BO4vNg/full, diakses pada tanggal 22 April 2021.

https://finance.detik.com/berita-ekonomi-bisnis/d-4727901/ulah-kapal-nakal-lautkepulauan-riau-tercemar-limbah-minyak. diakses pada tanggal 22 April 2021.

\section{Peraturan Perundang-Undangan}

Pasal 194 Konvensi PBB tentang Hukum laut Internasional.

Undang-Undang Nomor 34 Tahun 2014 tentang Kelautan

Undang-Undang Nomor 6 Tahun 1996 tentang Perairan

Undang-Undang Nomor 32 Tahun 2009 tentang Perlindungan dan Pengelolaan Lingkungan Hidup

Peraturan Pemerintah No. 41 Tahun 1999 tentang Pengendalian Pencemaran

Peraturan Pemerintah No. 82 Tahun 2001 tentang Pengelolaan Kualitas Air

Peraturan Pemerintah No. 101 Tahun 2014 tentang Pengelolaan Bahan berbahaya dan beracun (B3) 